\title{
Identifikasi Faktor Yang Mempengaruhi Mahasiswa UIN Alauddin Makassar Dalam Berbelanja Online
}

\author{
Adiatma \\ Prodi Matematika FST, UINAM, Adiatma.rasyid@uin-alauddin.ac.id \\ Adnan Sauddin \\ Prodi Matematika FST, UINAM, Adnan.sauddin@uin-alauddin.ac.id
}

Karmatang

Prodi Matematika FST, UINAM

\begin{abstract}
ABSTRAK, Konsep belanja di masyarakat mengalami perkembangan dengan adanya belanja online. Belanja online pun semakin populer di kalangan mahasiswa yang bisa dilihat dengan meningkatnya pola transaksi belanja online yang semakin hari semakin meningkat. Beberapa faktor yang menyebabkan seseorang atau mahasiswa berbelanja online diantaranya menghemat waktu dan biaya, penyampaian informasi yang up to date, produk yang beraneka ragam, dapat membandingkan harga dengan mudah, dan konsumen dapat memberikan masukan atau saran apabila produk yang dipesan tidak sesuai dengan ekspektasi dan lain sebagainya. Penelitian ini bertujuan untuk mengetahui faktor-faktor yang mempengaruhi mahasiswa UIN Alauddin Makassar dalam Berbelanja Online. Metode yang digunakan pada penelitian ini adalah EFA (Exploratory Factor Analysis). Hasil penelitian berdasarkan menunjukkan bahwa terdapat 8 faktor yang mempengaruhi mahasiswa UIN Alauddin Makassar dalam berbelanja online yaitu kemudahan, pelayanan, ketersediaan media transaksi, kualitas informasi, keamanan, potongan harga, profesionalisme, dan kepercayaan.
\end{abstract}

Kata Kunci: EFA (Exploratory Factor Analysis), nilai eigen, proporsi kumulatif, PCA (Principal Component Analysis), rotasi varimax

\section{PENDAHULUAN}

Pada dasarnya belanja hanyalah suatu sikap mendapatkan barang untuk memenuhi kebutuhan sehari-hari dengan uang sebagai alat tukar atas barang tersebut. Namun saat ini, konsep belanja di masyarakat mengalami perkembangan, yaitu dengan adanya belanja online.

Belanja online pun semakin populer di kalangan mahasiswa, hal ini dapat dilihat dengan meningkatnya pola transaksi belanja online yang semakin hari semakin meningkat, karena konsumen dapat berbelanja kapanpun dan dimanapun, menghemat waktu dan biaya pembeli tidak perlu mengunjungi toko secara langsung, untuk membandingkan produk dan harga karena seluruh proses ini dilakukan melalui media internet, hal inilah yang membuat pembeli semakin produktif sehingga belanja online pun jadi pilihan. [1]

Terdapat beberapa faktor yang menyebabkan sesorang atau mahasiswa berbelanja online, Untuk mengetahui faktor yang paling berpengaruh maka diperlukan analisis pengelompokan. Berdasarkan pembahasan diatas maka peneliti menggunakan metode EFA (Exploratory Factor Analysis) dalam pengelompokan faktor yang berpengaruh terhadap mahasiswa UIN Alauddin Makassar dalam berbelanja online.

\section{TINJAUAN PUSTAKA}

\section{Analisis Faktor}

Analisis faktor merupakan salah satu metode yang bertujuan untuk mengetahui faktor-faktor yang berpengaruh atau berkorelasi tinggi terhadap indikator-indikator yang diteliti.[2]

Adapun modelnya yaitu:

$X_{1}-\mu_{1}=l_{11} F_{1}+l_{12} F_{2}+\ldots l_{1 m} F_{m}+\varepsilon_{1}$

$X_{2}-\mu_{2}=l_{21} F_{1}+l_{22} F_{2}+\ldots l_{2 m} F_{m}+\varepsilon_{2}$

$\vdots \vdots \vdots \vdots:$

$X_{p}-\mu_{p}=l_{p 1} F_{1}+l_{p 2} F_{2}+\ldots l_{p m} F_{m}+\varepsilon_{p}$

Tahapan-tahapan analisis faktor

1. Membentuk matriks korelasi

Matriks korelasi bertujuan untuk mengetahui variabel-variabel yang saling berhubungan.

$$
\rho=\left(v^{1 / 2}\right)^{-1} \Sigma\left(v^{1 / 2}\right)^{-1}
$$


2. Melakukan Pengujian Terhadap Matriks Korelasi

Pada analisis ini variabel yang mempunyai multikolinearitas antara beberapa variabel yang memiliki koefisien korelasi relatif tinggi, kemudian akan dipilih salah satu untuk dianalisis lebih lanjut (Barlett's Test of Sphericity). Selanjutnya gunakan uji KMO (Kaiser Mayer-Olkin) bertujuan untuk mengetahui syarat kecukupan data yang digunakan dalam analisis. Besaran KMO dikatakan layak untuk dianalisis apabila nilainya minimal 0,5. Selanjutnya adalah melihat nilai MSA (Measure Of Sampling Adequency). MSA digunakan sebagai indikator dalam menentukan analalisis dapat dilanjutkan atau tidak dengan kriteria $M S A \geq 0,5 .[3]$

\section{Ekstraksi Faktor}

Ekstraksi faktor bertujuan untuk mereduksi sejumlah variabel asli (misalkan sebanyak $p$ variabel) menjadi sejumlah faktor kecil (misalkan $k$ faktor) dimana $p \leq$ k. [4]

Penentuan mengenai banyaknya jumlah faktor yang terbentuk dapat dilakukan melalui beberapa metode yaitu sebagai berikut:

a. Penentuan berdasarkan nilai eigenvalue Apabila suatu variabel memiliki nilai eigenvalue $>1$, maka dinyatakan sebagai komponen. Begitupun sebaliknya eigenvalue suatu variabel $<1$ maka akan dianalisis dikomponen manakah variabel tersebut dimasukkan.

b. Penentuan berdasarkan scree plot

Penentuan berdasarkan scree plot
merupakan gambaran dari hasil perhitungan nilai eigen.

c. Penentuan berdasarkan nilai proporsi varian kumulatif

Persentase varian merupakan jumlah variasi yang berhubungan pada suatu faktor yang dinyatakan dalam bentuk persentase. Penentuan jumlah faktor menggunakan nilai proporsi kumulatif ini tidak memiliki standar baku ada yang menyebutkan $70 \%, 80 \%$ atau
90\%. Tapi alangkah baiknya mendekati $100 \%$.

\section{Rotasi Faktor-faktor}

Rotasi faktor berfungsi memudahkan proses interpretasi dalam menentukan variabel-variabel dalam suatu faktor terhadap variabel yang berkorelasi tinggi dengan beberapa faktor atau ada beberapa memiliki faktor loading yang bernilai dibawah standar dari ketentuan yang berlaku.[5]

Metode yang digunakan pada penelitian ini metode varimax yang berguna meminimalkan jumlah faktor untuk menjelaskan indikator.

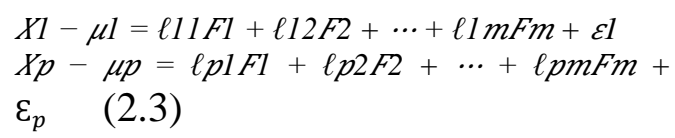

\section{Pembelian online}

Pembelian online merupakan kegiatan pembelian barang dan jasa melalui media internet. Kegiatan belanja online merupakan salah satu bentuk perdagangan elektronik yang komunikasinya tidak memerlukan tatap muka secara langsung pembeli bisa melihat dan mempelajari barang yang akan di belinya melalui web yang di promosikan oleh penjual.[6]

\section{METODOLOGI}

Data mahasiswa UIN Alauddin Makassar yang pernah berbelanja online didapatkan dari kuisioner yang disebar secara online yang berjumlah sebanyak 348 mahasiswa.

\section{Prosedur Analisis}

Langkah-langkah analisis yang digunakan untuk mengetahui faktor-faktor yang berpengaruh terhadap mahasiswa UIN Alauddin Makassar dalam berbelanja online dengan menggunakan metode EFAdijelaskan sebagai berikut:

1. Menghitung matriks korelasi antar variabel

2. Melakukan pengujian terhadap matriks korelasi dengan menggunakan uji KMO (Kaiser-Meiyer-Olkin), uji Bartlett's dan uji MSA (Measure of Sampling). 
3. Melakukan ekstraksi faktor, menggunakan metode Principal Component Analysis (PCA).

4. Menentukan banyaknya faktor, dengan memilih salah satu metode berikut:

a. Menggunakan nilai eigen $>1$.

b. Menggunakan scree plot.

c. Menggunakan proporsi varian kumulatif terhadap totalnya.

5. Melakukan rotasi faktor dengan menggunakan metode varimax.

6. Interpretasikan faktor

\section{PEMBAHASAN}

\section{Data Penelitian}

Terdapat 348 data yang akan dimodel

Tabel 1 Data Mahasiswa UIN Alauddin Makassar yang Pernah Berbelanja Online

\begin{tabular}{ccccc}
\hline Variabel & 1 & 2 & 3 & 4 \\
\hline $\mathrm{X}_{1}$ & 0 & 0 & 144 & 204 \\
$\mathrm{X}_{2}$ & 0 & 17 & 147 & 184 \\
$\mathrm{X}_{3}$ & 0 & 0 & 176 & 172 \\
$\mathrm{X}_{4}$ & 0 & 0 & 309 & 39 \\
$\mathrm{X}_{5}$ & 0 & 0 & 181 & 167 \\
$\mathrm{X}_{6}$ & 0 & 2 & 188 & 158 \\
$\mathrm{X}_{7}$ & 0 & 0 & 157 & 191 \\
$\mathrm{X}_{8}$ & 0 & 10 & 251 & 87 \\
$\mathrm{X}_{9}$ & 0 & 0 & 316 & 32 \\
$\mathrm{X}_{10}$ & 0 & 10 & 284 & 54 \\
$\mathrm{X}_{11}$ & 0 & 11 & 272 & 65 \\
$\mathrm{X}_{12}$ & 0 & 0 & 281 & 67 \\
$\mathrm{X}_{13}$ & 0 & 29 & 257 & 62 \\
$\mathrm{X}_{14}$ & 0 & 43 & 265 & 40 \\
$\mathrm{X}_{15}$ & 0 & 55 & 260 & 33 \\
$\mathrm{X}_{16}$ & 0 & 35 & 271 & 42 \\
$\mathrm{X}_{17}$ & 0 & 13 & 301 & 34 \\
$\mathrm{X}_{18}$ & 0 & 51 & 270 & 27 \\
$\mathrm{X}_{19}$ & 0 & 27 & 304 & 17 \\
$\mathrm{X}_{20}$ & 0 & 211 & 8 & 129 \\
\hline
\end{tabular}

Sumber data:Kuisioner yang disebar secara online

Tabel 2 Hasil Uji Validitas Kuisioner Item

\begin{tabular}{cccc}
$\begin{array}{c}\text { Pertanyaan } \\
\text { ke }\end{array}$ & rhitung & r tabel & Keterangan \\
\hline Pert 1 & 0,5664 & 0,113 & Valid \\
Pert 2 & 0,4838 & 0,113 & Valid \\
Pert 3 & 0,4584 & 0,113 & Valid \\
Pert 4 & 0,2552 & 0,113 & Valid \\
Pert 5 & 0,4879 & 0,113 & Valid \\
Pert 6 & 0,5608 & 0,113 & Valid
\end{tabular}

\begin{tabular}{llll} 
Pert 7 & 0,6101 & 0,113 & Valid \\
Pert 8 & 0,4909 & 0,113 & Valid \\
Pert 9 & 0,1990 & 0,113 & Valid \\
Pert 10 & 0,4789 & 0,113 & Valid \\
Pert11 & 0,5078 & 0,113 & Valid \\
Pert12 & 0,4166 & 0,113 & Valid \\
Pert13 & 0,4897 & 0,113 & Valid \\
Pert14 & 0,4608 & 0,113 & Valid \\
Pert15 & 0,3956 & 0,113 & Valid \\
Pert16 & 0,4128 & 0,113 & Valid \\
Pert17 & 0,4396 & 0,113 & Valid \\
Pert18 & 0,3683 & 0,113 & Valid \\
Pert19 & 0,2070 & 0,113 & Valid \\
Pert20 & $-0,4363$ & 0,113 & Tidak valid \\
\hline
\end{tabular}

Berdasarkan tabel uji validitas diatas menunjukkan bahwa hanya item pert20 yang tidak memenuhi syarat validitas $r_{\text {hitung }}>r_{\text {tabel }}$ sehingga item pernyataan tersebut dinyatakan tidak valid sehingga dikeluarkan dari kuisioner.

Tabel 3 Hasil uji reliabilitas

\begin{tabular}{|l|}
\hline Reliability Alpha $=0,8175$ \\
\hline Standardized Alpha $=0,8198$ \\
\hline
\end{tabular}

Berdasarkan tabel diatas, nilai Cronbach Alpha lebih besar dari 0,70 sehingga dapat disimpulkan bahwa semua item pernyataan memenuhi syarat reliabel.

\section{Menghitung Matriks Korelasi}

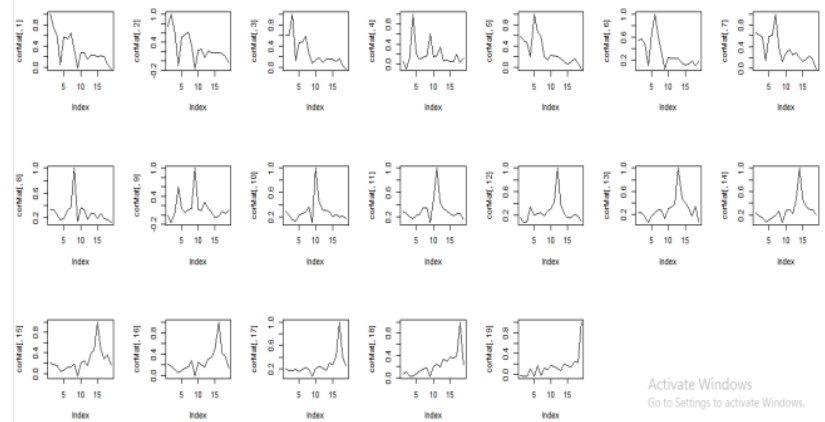

Gambar 1 Matriks korelasi yang terbentuk

Dari hasil analisis perhitungan korelasi maka didapatkan matriks korelasi seperti pada Gambar 1.

\section{Melakukan Pengujian Terhadap Matriks Korelasi}

Layak atau tidaknya suatu variabel dilakukan analisis faktor maka perlu dilakukan pengujian terhadap matriks korelasinya dengan menggunakan uji Kaiser-Meyer-Olkin (KMO) measure of adequacy (MSA) dan Bartlett Test 
of Spericity, dimana nilai KMO harus lebih besar dari 0,5 nilai MSA berkisar dari 0 sampai 1 dan Uji Bartlett's test of sphericity. Dimana dalam uji ini nilai $p$-value harus lebih kecil dari 0,05 .

Tabel 4 KMO and Bartlett's Test

\begin{tabular}{|c|c|c|c|}
\hline Khi-squared & Df & p-value & KMO \\
\hline 2485,284 & 171 & $<2,22 \mathrm{e}-16$ & 0,85 \\
\hline
\end{tabular}

Berdasarkan Tabel 2, didapatkan nilai $\mathrm{KMO}=$ 0,83 dengan taraf signifikan $5 \%$ dimana 0,85 $>0,5$ sehingga $\mathrm{H}_{0}$ diterima, maka dapat disimpulkan bahwa jumlah data cukup untuk difaktorkan dan di dapatkan nilai $p$-value $=<$ 2,22e-16 atau 0,000. Dimana 0,000 < 0,05 sehingga $\mathrm{H}_{0}$ ditolak, sehingga dapat disimpulkan bahwa variabel dapat dilanjutkan analisisnya yaitu analisis faktor.

Tabel 5 Measure of Sampling Adequacy (MSA)

\begin{tabular}{|l|l|l|l|}
\hline Item & MSA & Item & MSA \\
\hline Pert1 & 0,89 & Pert11 & 0,87 \\
\hline Pert2 & 0,86 & Pert12 & 0,83 \\
\hline Pert3 & 0,91 & Pert13 & 0,84 \\
\hline Pert4 & 0,64 & Pert14 & 0,88 \\
\hline Pert5 & 0,85 & Pert15 & 0,81 \\
\hline Pert6 & 0,84 & Pert16 & 0,84 \\
\hline Pert7 & 0,91 & Pert17 & 0,83 \\
\hline Pert8 & 0,90 & Pert18 & 0,84 \\
\hline Pert9 & 0,61 & Pert19 & 0,65 \\
\hline Pert10 & 0,89 & & \multicolumn{1}{|l}{} \\
\hline
\end{tabular}

Berdasarkan Tabel 5 nilai MSA yang didapatkan untuk setiap variabel adalah lebih besar dari 0,5 dengan taraf signifikan $5 \%$, sehingga dapat disimpulkan bahwa semua variabel masih bisa diprediksi dan dapat dilakukan analisis lebih lanjut

\section{Ekstraksi Faktor}

Ekstraksi faktor dapat dilakukan dengan memilih salah satu metode berikut ini:

1. Penentuan berdasarkan nilai

Tabel 6 Nilai Eigenvalue

\begin{tabular}{cccc}
\hline Component & $\begin{array}{c}\text { Eigen } \\
\text { value }\end{array}$ & component & $\begin{array}{c}\text { Eigen } \\
\text { value }\end{array}$ \\
\hline 1 & $\mathbf{5 , 4 1 0}$ & 11 & 0,569 \\
2 & $\mathbf{2 , 5 3 2}$ & 12 & 0,494 \\
3 & $\mathbf{1 , 8 5 1}$ & 13 & 0,439
\end{tabular}

\begin{tabular}{llll}
4 & $\mathbf{1 , 1 4 0}$ & 14 & 0,407 \\
5 & $\mathbf{1 , 0 1 9}$ & 15 & 0,373 \\
6 & 0,863 & 16 & 0,336 \\
7 & 0,825 & 17 & 0,313 \\
8 & 0,702 & 18 & 0,284 \\
9 & 0,635 & 19 & 0,215 \\
10 & 0,592 & & \\
\hline
\end{tabular}

Eigenvalue yang memiliki nilai lebih besar dari 1 menyatakan jumlah komponen. Berdasarkan Tabel 6 menunjukkan bahwa terdapat 5 komponen yang dijadikan sebagai komponen utama

2. Penentuan berdasarkan scree plot

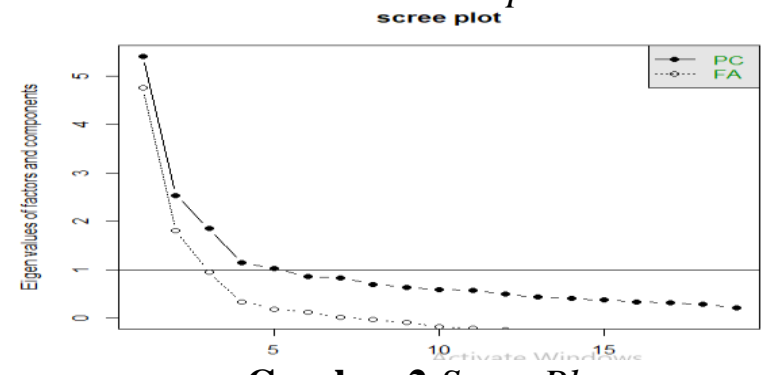

Gambar 2 Scree Plot

Nilai eigenvalue yang telah didapatkan kemudian di plot, sehingga menghasilkan scree plot. Hal ini dapat dilihat pada Gambar 2 yang menunjukkan terbentuknya 5 komponen utama.

3. Penentuan berdasarkan nilai proporsi kumulatif

Penentuan berdasarkan nilai proporsi varian kumulatif, tidak ada standar baku mengenai penentuan nilai proporsi ini, akan tetapi nilai yang baik berada pada rentang nilai 70 sampai 90 persen.

Berdasarkan nilai eigen yang telah diperoleh, apabila menggunakan nilai eigenvalue sebagai penentuan jumlah faktor maka hanya terdapat 5 faktor yang memiliki nilai eigen lebih besar dari 1 dan hanya mampu menjelaskan varian sebanyak 62,91 persen saja. Maka dalam penelitian ini penentuan jumlah faktor yang digunakan adalah nilai proporsi kumulatif sehingga terbentuk 8 faktor yang mampu menjelaskan varians sebesar 75,48 persen. 
Tabel 7 Dekomposisi Nilai Eigenvalue

\begin{tabular}{|c|c|c|c|}
\hline Komponen & $\begin{array}{c}\text { Nilai } \\
\text { Eigenvalue }\end{array}$ & $\begin{array}{c}\text { Proporsi } \\
\text { Varians } \\
(\%)\end{array}$ & $\begin{array}{c}\text { Proporsi } \\
\text { Kumulatif } \\
(\%)\end{array}$ \\
\hline 1 & 5,410 & 0,2848 & 0,2848 \\
\hline 2 & 2,532 & 0,1333 & 0,4180 \\
\hline 3 & 1,851 & 0,0974 & 0,5154 \\
\hline 4 & 1,140 & 0,06002 & 0,57545 \\
\hline 5 & 1,019 & 0,05363 & 0,62908 \\
\hline 6 & 0,863 & 0,04541 & 0,67449 \\
\hline 8 & 0,702 & 0,03696 & 0,75486 \\
\hline 9 & 0,635 & 0,03341 & 0,78827 \\
\hline 10 & 0,592 & 0,03116 & 0,81943 \\
\hline 11 & 0,569 & 0,02994 & 0,84937 \\
\hline 12 & 0,494 & 0,02599 & 0,87536 \\
\hline 13 & 0,439 & 0,02316 & 0,89851 \\
\hline 14 & 0,407 & 0,02142 & 0,91994 \\
\hline 15 & 0,373 & 0,01964 & 0,93958 \\
\hline 16 & 0,336 & 0,01769 & 0,95726 \\
\hline 17 & 0,313 & 0,01649 & 0,97375 \\
\hline 18 & 0,284 & 0,01495 & 0,98870 \\
\hline 19 & 0,215 & 0,0113 & 1,0000 \\
\hline
\end{tabular}

\section{Rotasi Faktor}

Pada rotasi faktor ini digunakan metode varimax dimaksudkan agar mendapatkan struktur faktor yang terdiri dari kombinasi variabel-variabel yang memiliki nilai loading factor sangat tinggi hanya pada satu faktor saja. Components Analysis

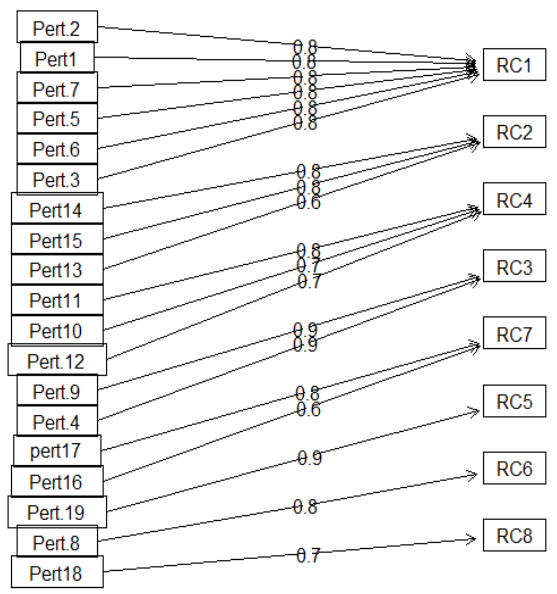

Gambar 3 Graph Factor Loading Matrices
Berdasarkan Gambar 3 di atas menunjukkan bahwa ada 8 faktor yang terbentuk.

\section{Interpretasi Hasil}

Tabel 8 Hasil Interpretasi Variabel

\begin{tabular}{|c|c|c|c|c|c|c|}
\hline No & Var & Faktor & $\begin{array}{l}\text { Eigen } \\
\text { Value }\end{array}$ & $\begin{array}{c}\text { Loading } \\
\text { Faktor }\end{array}$ & $\begin{array}{l}\text { Vari } \\
\text { ansi } \\
(\%)\end{array}$ & $\begin{array}{l}\text { Kum } \\
\text { ulatif } \\
(\%)\end{array}$ \\
\hline 1. & $\mathrm{X} 1$ & & & 0,81 & & \\
\hline 2. & $\mathrm{X} 2$ & & & 0,81 & & \\
\hline 3. & X3 & Kemudahan & 5,410 & 0,76 & 28,4 & 28,48 \\
\hline 5. & X6 & & & 0,79 & & \\
\hline 6. & $\mathrm{X} 7$ & & & 0,80 & & \\
\hline 8. & X14 & Pelayanan & & 0,76 & & \\
\hline 9. & $\mathrm{X} 15$ & & & 0,61 & & \\
\hline 10. & $\mathrm{X} 4$ & & & 0,87 & & \\
\hline 11. & $\mathrm{X} 9$ & $\begin{array}{l}\text { Ketersediaan } \\
\text { Media } \\
\text { transaksi }\end{array}$ & 1,851 & 0,88 & 9,74 & 51,54 \\
\hline 12. & $\mathrm{X} 10$ & & & 0,68 & & \\
\hline 13. & $\mathrm{X} 11$ & Kualitas & 1,140 & 0,80 & 6 & 57,54 \\
\hline 14. & $\mathrm{X} 12$ & Informasi & & 0,67 & & \\
\hline 15. & X19 & Keamanan & 1,019 & 0,94 & 5,36 & 62,91 \\
\hline 16. & $\mathrm{X} 8$ & $\begin{array}{l}\text { Potongan } \\
\text { Harga }\end{array}$ & 0,863 & 0,82 & 4,54 & 67,45 \\
\hline 17. & X16 & $\begin{array}{l}\text { Profesionali } \\
\text { sme }\end{array}$ & 0,825 & 0,64 & 4,34 & 71,79 \\
\hline 18. & $\mathrm{X} 17$ & & & 0,84 & & \\
\hline 19. & $\mathrm{X} 18$ & $\begin{array}{l}\text { Kepercayaa } \\
\mathrm{n}\end{array}$ & 0,702 & 0,72 & 3,69 & 75,48 \\
\hline
\end{tabular}

Berdasarkan tabel 8, maka peneliti menentukan untuk mengambil 8 faktor sebagai komponen utama yaitu FAKTOR $1\left(\mathrm{~F}_{1}\right)$ sampai FAKTOR $8\left(\mathrm{~F}_{8}\right)$. Meskipun dalam penentuan jumlah faktor berdasarkan nilai proporsi kumulatif lebih memprioritaskan nilai yang lebih tinggi. Akan tetapi, jika jumlah faktor terlalu banyak maka akan menyalahi fungsi analisis faktor itu sendiri yaitu mereduksi dan jumlah faktor yang banyak akan mempersulit dalam proses interpretasi. Adapun kedelapan faktor yaitu kemudahan, pelayanan, ketersediaan media transaksi, kualitas informasi, keamanan, potongan harga, profesionalisme dan kepercayaan.

\section{KESIMPULAN}

Pembahasan hasil menunjukkan bahwa terdapat delapan faktor yang mempengaruhi mahasiswa UIN Alauddin Makassar dalam berbelanja online yaitu kemudahan, pelayanan, ketersediaan media transaksi, kualitas informasi, 
keamanan, potongan harga, profesionalisme dan kepercayaan.

\section{DAFTAR PUSTAKA}

[1] Lestari, Sri Budi. 2105. Shopping Online Sebagai Gaya Hidup. Jurnal Ilmu Sosial. Vol.14 no.2. h.1.

[2] Joseph F.Hair, Jr.William C.Black Barr, J.Babin Rolph E.Anderson Seventh Edition. 2014. Multivariate Data Analysis (Amerika: United States of America). h.92.

[3] Widayat. 2018. Statistika Multivariat. Malang:UMM Press. h.21.

[4] Nugroho, Sigit P.hD. 2008. Statistika Multivariat Terapan. Bengkulu:UNIB Press. h.16.

[5] Supranto. 2004. Analisis Multivariat Arti dan Interpretasi. Jakarta: PT.RINEKA CIPTA. h.128.

[6] Tety Elida dan Ari Raharjo. 2019. Pemasaran Digital. Bogor: IPB Press. h.78. 